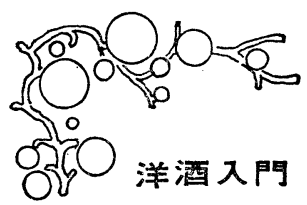

\title{
Prepared Cocktail
}

\section{カクテルのびん詰}

穂 積 忠 彦

（富士醗酵工業株式会社）

洋酒入門も, 回を重小, ウイスキー,ブランデー, ジ ン, リキュール, テキーラ, ラム, オコレホー, ミード, ウォッカ, アラック等世界中の酒を網羅して来た。しか し, これらの酒類とは別に, アメリカを中心として, 「スペシャリティ」と呼ばれ，「カクテルのびん詰」と呼 ばれる一連の洋酒が販売されている。今, ためしに, 上 述の世界中の酒類を分類学的に「門, 綱, 目, 科, 属, 種」と, 私達がその昔, 学校で生物学の勉強でならった 分類手法を応用して位置づとて見ると,「スペシャリ ティ」及び「カクテルのびん詰」はさしずめ, 酒類の分 類の「属」に属する酒類ということにならう(注 1 )。も ラ一つ見方をかえて見よう。

カクテルという洋酒の飲み方は約 100 年前にアメリカ で創作されたといわれている。カクテルについては，前 月号の洋酒入門で書かせてもらったが, もら一度, 簡単 にここで説明すると, カクテルとは主体となる酒（べー ス又は基酒と呼ばれる）に，その他の酒類，果汁，スパ イス, 氷などを混合し, 飲酒の直前に調合して飲む酒と いうことになっている。そして,このカクテルという飲 酒の方法は, リキュール, ブランデー, ウイスキー, ス ピリッツなど, 分類上の「目」に属する酒類が多種, 手 に入るようになってから考えだされたのである。アメリ

注 1 「門」〜酒類, 「綱」〜醸造酒, 蒸留酒, 混成酒, 「目」〜ワイン，ビール，ウイスキー，ウオッカ， ラム, ブランデー等,「科」〜ボルドーワイン, ラインワイン，スコッチウイスキー，バーボンウ イスキー, コニヤック，カルバドス等々となり， 「属」は科に属する酒類の小分類となるか，「科」 に属する酒を材料として作りだしたすのとなる。

注 2 アメリカは植民地的新興国で, 伝統に根ざした, らまい酒がなかったので，まぜあわせて，砂糖， 果汁, 氷などを入れ, 飲み易くして飲む方法が発 達した。我国の焼酎の「ぶどら割り」,「梅割り」 を考えていただけばよい。
カニズムで代表される「アメリカの風土的条件」（注 2) と,「氷」の供給を容易にした機械文明の発達によっ て，カクテルは完成し普及したものといえないことはな い。

ところで,ささざまに命名されたカクテルの調合法が 発表されるようになると, これらカクテルの中の有名な ものは, 調合された状態でびん詰され, 商品化出来る見 通しがついて来たし, 消費者の方からも, カクテルのび ん詰品を要求する声が出て来たのである。

いうならば洋酒の「インスタント・ラーメン」版であ る。「インスタント・ラーメン」の場合には熱湯が必要 であるが，「カクテルのびん詰」の場合には氷があれば よいわけである。「びん詰のカクテル」を氷で冷やし, グラスに注げば，たちどころに，立派なカクテルが出来 上るといら次第である。

このよ5な酒類は, 私達の酒類分類の概念でい党ば, ぞうしても「属」に属するものといわざるを得ない。と ころで, このような酒が, どの位, 世界中で作られてい るかを調べて見ると，実に意外なほど沢山あるのである。

\section{「スペシャリティ」と「カクテルのびん詰」}

洋酒業界の慣用語で「スペシャリティ」(Speciality 特殊品）と呼ばれている製品の有名なものを表にして見 た。これは厳密にいえば「カクテルのびん詰」とは言葉 のニュアンスに，ちょっとしたらがいがある。「カクテ ルのびん詰」といえば,すでにカクテルの処方で有名な 「マンハッタン・カクテル」,「マルティーニ・カクテル」, 「オールドファションド・カクテル」などのびん詰品で あり, 誰がぞこで作っても, 処方に間違いがなければ, 一応「マンハッタン」は「マンハッタン」である。とこ らが「スペシャリティ」となると, これは, きまった土 地で, その土地特産の酒類や, 香味料を独特の処方でブ レンドしたものであり, その処方が秘密にされ，よそで 
世界の主要スペシャりティ

\begin{tabular}{|c|c|}
\hline 称 & 地 \\
\hline $\begin{array}{l}\text { Cordial Medoc コーディアルメドック } \\
\text { Drambuie ドラムビィ }\end{array}$ & 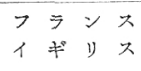 \\
\hline Forbidden Fruit フォービドンフルーツ & $P \times y \rightarrow$ \\
\hline  & 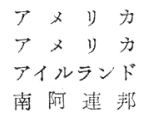 \\
\hline Falernumファレルナム & \\
\hline
\end{tabular}

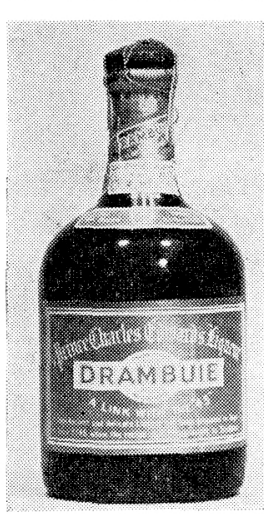

スペシャリティの 代表「ドランビ イ」。日本でも高 制バーでは見つけ ることが出来る。 強精効果も云々さ れている。

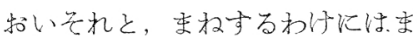
いら奴ものである。例克ば，写真 の「ドラムビイ」はスコットラン ド産の有名な「スペシャリティ、 で女り，わが国でも意外々愛好者 が多い(注 3 )。これは 1745 年に Prince Charles Edward ヒつい て来たフランス人の古代秘法に上 るとラベル比かれている。これ は上質の古いイアンド・モルト ・スコッチウイスキーを台にし， はちみつと, 種々のスパイスを配 しなものといわれている。

\section{最も古いカクテルのびん詰}

「アドボカート」は岕委りに有名で める。これはブランデーに卵黄と 砂糖を調合した強北酒で，アルコール分は18\% 前後， わが国でも，数社が発売している。これは「エッグ・ノ ッグ」のびん詰品と考兄てよい。「エッグ・ノッグ」は 有名なカクテルの一種で、いくつかの処方があるが，そ の代表的店ものは,

$$
\begin{array}{llll}
\text { ブランデー } & 30 \mathrm{~m} l & \text { 砂糖 } & \text { 3 茶匙 } \\
\text { ラム } & 15 \mathrm{~m} l & \text { ミルク } & 150 \mathrm{~m} l \\
\text { 留 } & 1 \text { 個 } & &
\end{array}
$$

以上を确いた氷とともによくシェークし，中型タンブ ラーに注ぎ，ナッッメッグを少量振りか子て供する。

イタリアには卵とマルサラ酒（イタリアのシシリー白 産の甘味ぶどら酒）莸混命した Marsala alluovo, 略し てマルボといら酒がめり, これはアメリカに盛んに輸出 されている。これなどは「アドボカート」の変種, すな わち、「ェッグ・ノッグ」の変種のびん詰品といえよう。 わが国でも風邪をひいたときに作って飲む「玉子酒」は 清酒を用いた，日本古来の「清酒のカクテル」でめる。

\section{輸入されたカクテルのびん詰}

現在，酒類輸入商社でをる $\mathrm{A}$ 社に上って輸入されてい

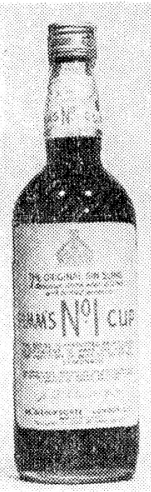

ピムス No.1 ジンスリング のびえ詰。こ れでピムスの 評判をとった



ピムス No. 3 ブランデース 1ングのびん 詰である。レ モネードで割 るとすばらし い飲物になる とラベールの 正面に記され ている
る「カクテルのびん詰」。 に「ピムス」がある。 れは現在 No. 1 No. 5 京 で 5 種類の処方のちがっ たものが岁るといらが, わが国に輸入されたもの はNo.1〜No. 4 实での 4 種類である。

ピム大 No. 1

(カクテル名 ジン。 スリング) ピムス No. 2

(カクテル名 ウイス キー・スリング)

ピムス No. 3

(カリテル名 ブラン デー・スリング)

ピムス No. 4

(カクテル名 ラム・ ブランデー・スリング)

グラスに注ざ、レモネードを割って飲毛ように指定さ れているが，パーテイドリンクとして使われることが多 い。ピムス社のロンドンの事務所で客化飲主垃たカクテ ルが非常に美味で, 遂にびん詰して欲しいとい5要求が 寒を結んで作りだされな製品であるといわれている。

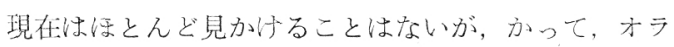
ンダの有名なリキュールメーカで女るボル大社のママン ハッタン」,「マティーニ」など数種の「カタテルのびん 詰」が輸入されたことも出った。

\section{わが国では}

「ジンフィズ」のびん詰がM社から「「イボール」の かん詰として「ウイスタン」が $\mathrm{S}$ 社から売り出されてい るが，これらが最も代表的なかが国での「カクテルのび ん, かん詰」であろう。また，G社の「電気ブラン」,

注 3 この酒については強精効果が盛んに煊层されて いる。 
「ブランドール」などは，いうならば，日本版「スペシ ヤリティこである。

\section{ひとつの問題点}

ピムスのうカクテルのびん詰」の起りは上述のと挌り である。ところで, 日本ではどうなるか, ちょっと考光 て見よう。例党ば「ホテル・ヤ、トの酒場のチーフバー テンダーH氏が独特の美味なカクテルを作り, それが段 々と評判になったとしょう。遂に「明日，一家でピクニ ックにゆくえだから, びん詰で欲しい」という，扔客の 声が高まって来る。そして, 扮客の要望で「ヤマト・カ クテル No.1」という名称で, びん詰して売ることを考 光たとしよう。わが国の現行酒税法では，これは許され ない行為である。「酒類の混和」はあくまで消費の直前 にのみ許されて揓り，乙かも，バー，酒場，レストラン は「酒類の小売」を兼業出来ない。大げさにい党ば「無 免許製造」そ「無免許販売」の 2 つの罪を犯すことにな るわけで岀る。日本人の酒類の消費がバラェティにとえ だものとなり, 洋風化するにつれて, 現行酒税法がムジ ニンをはらんだものになる好例かも知れない。

\section{アメリカのカクテルのびん詰}

アメリカの有名な酒類市況及び価格専門雑誌「Beverage Media」をひらいて見ると「PPrepared Cocktails」 が1ベージをうめていた。さすがに，カクテルの本場の アメリカである。有名な Hiram Walker 社, Heublein 社をはじめ, 20 社に近いメーカーが「マンハッタン」, 「マルティーニ」,「エッグ・ノッグ」,「ウォッカ・マテ イーニ」,「エッグ・ノッグ」,「サイドカー」,「オールド ・ファションド」,「ダイキリ」,「スティンガー」,「ウイ スキー・サワー」,「ジン・サワー」,「スクリュー・ドライ バー上など有名な処方のカクテルをいずれる,びん詰品
として発売している。これら製品の中には Ice Box Cocktails 又は Refrigerator Cocktail (冷蔵庫カクテル) と名付け，冷やしさえすれば飲めるといらイメージを盛 り上げているものや, Instant Cocktail for two (2人 のための即席カクテル）と銘をらち, 恋人達が簡単に飲 めるものであることを強調したものもある。更に興味深 いのは Banquet (宴会用) という名前のついたカクテル のびん詰が売りだされていることである。これはバー専 用のものである。アメリカでは, バー, 料飲店等業務笳 には問屋が直接販売し, 小売屋と同列になっているので, このような製品は卸価格のみで, 小売価格が表示されて いない。同じょうなカクテルには, Schenley 社の「Professional Cocktail」(業務用カクテル) がある。括先ら く, アメリカのように労賃の高いところでは, カクテル を作る職人としてのバーテンダーが払底し，びん詰カク テルをグラスに注ぐ程度にしなければ，やってゆけない 店が多くなっているのではないだろうか，そして，この ような人手不足が「カクテルのびん詰品」を売り出して も，充分，ビジネスになる状況を生んでいるのではない だろらか。参考要でにいうと, Heublein 社の「マンハ ッタン・カクテル」(アルコール分 $27.5 \%$ ) $4 / 5$ クォ ート $(757 \mathrm{ml})$ で小売価格 1 本 1.99 ドルである。

$$
\text { おわりに }
$$

わが国の酒類消費のパタンは，その大部分がビールと 清酒で彷りぶされている。しかし, 戦後, ウイスキー をはじめとする洋酒の消費量もめざすしく上って来た。 そして, カクテルといら言葉も一般化し, 洋酒は, バー から家庭にまで進出して来た。現在のところ, ごくわず かのめば党しか見られないが，わが国でも「カクテルの びん詰品」の需要が出て来る可能性もないわけではな い。

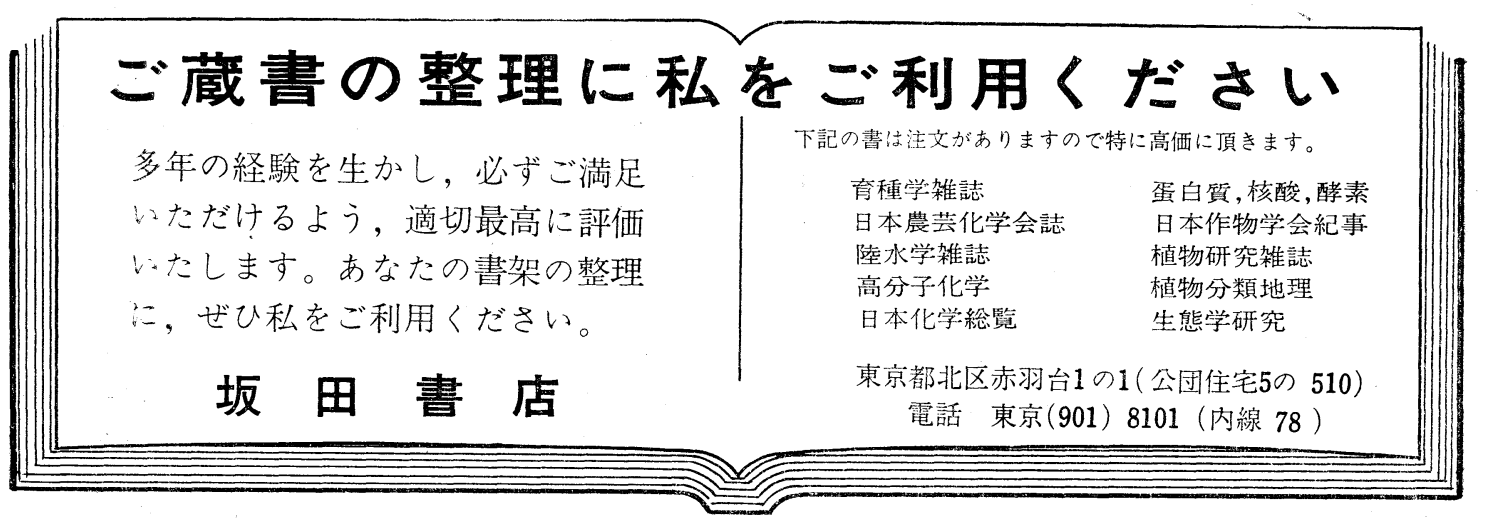

